\title{
Corrosion Inhibition of Mild Steel by 4-Allyl-5-pyridin-4-yl-4H-1,2,4-triazole-3-thiol
}

\author{
A. ORHAN ${ }^{\mathrm{a}}$, D. ERCAN ${ }^{\mathrm{b}}$, P. KOPARIR ${ }^{*}$ and A. SOYLEMEZ ${ }^{\mathrm{b}}$ \\ ${ }^{a}$ Department of Metal, Faculty of Technical Education, Firat University, \\ 2311 Elazig, Turkey \\ ${ }^{\mathrm{b}}$ Department of Chemistry, Faculty of Science, Firat University, 23119, Elazig, Turkey \\ *Department of Chemistry, Forensic Medicine Institute, TR-4400, Malatya, Turkey \\ pelin.kutulay@adalet.gov.tr
}

Received 22 May 2012 / Accepted 13 June 2012

\begin{abstract}
Allyl-5-pyridin-4-yl-4H-1,2,4-triazole-3-thiol has been synthesized and characterized by $\mathrm{IR},{ }^{1} \mathrm{H}$ NMR, ${ }^{13} \mathrm{C}$ NMR analysis. The corrosion protection of mild steel in a $0.1 \mathrm{M} \mathrm{H}_{2} \mathrm{SO}_{4}$ solution by 4-allyl-5-pyridin-4-yl-4H-1,2,4-triazole-3-thiol was studied by electrochemical impedance spectroscopy (EIS) and scanning electron microscopy (SEM). Results showed that 4-allyl-5-pyridin-4yl-4H-1,2,4-triazole-3-thiol inhibited mild steel corrosion in a $0.1 \mathrm{M} \mathrm{H}_{2} \mathrm{SO}_{4}$ solution and indicated that the inhibition efficiencies increased with the concentration of inhibitor. Changes in impedance parameters suggested the adsorption of 4-allyl-5-pyridin-4-yl-4H-1,2,4-triazole-3-thiol on the mild steel surface, leading to the formation of protective films.
\end{abstract}

Keywords: 1,2,4-Triazole, Corrosion, Mild steel, Inhibition

\section{Introduction}

Mild steel is a well-known material used extensively in various industries. However, its tendency to corrode makes it unsuitable for exposure to acids. The use of inhibitors is one of the practical methods for protection against corrosion in acidic media ${ }^{1}$. Organic compounds have long been known to inhibit the corrosion of mild steel in acidic media. Compounds previously studied as inhibitors include triazole derivatives ${ }^{2-5}$, bipyrazolic derivatives ${ }^{6}$, surfactants $^{7,8}$, aromatic hydrazides ${ }^{9}$, organic dyes ${ }^{10,11}$, poly (4-vinylpyridine) ${ }^{12}$ and thiosemicarbazide-type organic compounds ${ }^{13,14}$. These compounds can adsorb on to the mild steel surface and block active sites, thus decreasing the corrosion rate.

Triazoles are important class of heterocyclic compounds. These compounds, riches in heteroatoms, such as sulfur, nitrogen and oxygen, can be used as environmentally friendly inhibitors because of their strong chemical activity and low toxicity ${ }^{15-20}$. Examples are triazole-type compounds containing several heterocyclic structures, which have excellent corrosion properties for the corrosion of many metals in various aggressive media ${ }^{21-23}$. 
The aim of this study is to investigate the inhibitive properties of title compound on the corrosion of the steel in $0.1 \mathrm{M} \mathrm{H}_{2} \mathrm{SO}_{4}$ solution. The chemical structure of the compounds studied is as follows (Figure 1).

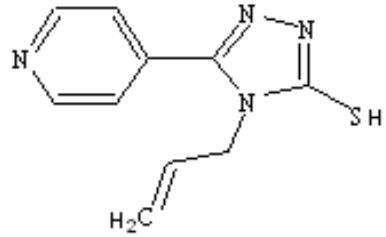

Figure 1. 4-Allyl-5-pyridin-4-yl-4H-1,2,4-triazole-3-thiol

\section{Experimental}

The synthesis of 4-allyl-5-pyridin-4-yl-4H-1,2,4-triazole-3-thiol was carried out according to a method are given in the literature ${ }^{24}$. The structures of synthesized compounds were confirmed by analytical and spectroscopic methods (FT-IR, ${ }^{1} \mathrm{H}$ NMR, ${ }^{13} \mathrm{C}$ NMR).

All reagents were of analytical grade. The stock solution of 4-allyl-5-pyridin-4-yl-4H1,2,4-triazole-3-thiol $\left(10^{-2} \mathrm{M}\right)$ was prepared in ethanol. Britton-Robinson buffer was used for varying $\mathrm{pH}$. Due to the low solubility of this compound in aqueous media, $10 \% \mathrm{v} / \mathrm{v}$ ethanol solutions were used. The cyclic voltammograms were recorded by a Metrohm Model 757 VA computrace with conventional three-electrode cell, glassy carbon electrode (GCE) as the working electrode, an $\mathrm{Ag} / \mathrm{AgCl} / \mathrm{KCl}_{\text {(sat) }}$ as the reference and Pt wire as counter electrode. All the voltammetric measurements were conducted at the room temperature under the argon atmosphere. The $\mathrm{pH}$ values were measured with $\mathrm{pH}$ meter Metrohm Model 744.

Mild steel specimens obtained from were used as the working electrodes throughout the study. The composition of the mild steel was: $\% 0.08 \mathrm{C}, \% 1 \mathrm{Mn}, \% 1 \mathrm{~S}, \% 16-18 \mathrm{Cr}, \% 14 \mathrm{Ni}$, $\% 0.04 \mathrm{P}, \% 0.03 \mathrm{~S}$. The cell contains three electrodes reference electrode, as working electrode comprised of mild steel, a glass electrode. The inhibiting action of this compound against the corrosion of carbon steel in $0.1 \mathrm{M} \mathrm{H}_{2} \mathrm{SO}_{4}$ solution was investigated by electrochemical techniques including electrochemical impedance spectroscopy. The potentiodynamic current-potential curves were swept from -0.25 to $+0.25 \mathrm{VSCE}$ at a scan rate of $0.5 \mathrm{mV} \backslash \mathrm{s}$. Impedance measurements were carried out using AC signals of $5 \mathrm{mV}$ peak to peak amplitude at the open circuit potential in the frequency range of $100 \mathrm{kHz}-0.1 \mathrm{~Hz}$. Electrochemical measurements were initiated about $30 \mathrm{~min}$ after the working electrode was immersed in solution to stabilize the steady state potential.

\section{Results and Discussion}

\section{Electrochemical behavior of 4-allyl-5-pyridin-4-yl-4H-1,2,4-triazole-3-thiol}

Koparir et al. reported that the crystal structure of thiol compounds corresponded to the thione form, but they showed thiol-thione tautomerism in solutions (Figure 2) ${ }^{24}$. Due to the thiol-thione tautomerism of 4-allyl-5-pyridin-4-yl-4H-1,2,4-triazole-3-thiol it mostly appeared thiol form in solution. Thus it has oxidizable - $\mathrm{SH}$ group. Therefore, the electrochemical behavior of 4-allyl-5-pyridin-4-yl-4H-1,2,4-triazole-3-thiol was studied by using cyclic voltammetric technique (CV) at GCE. In order to see the effect of $\mathrm{pH}$ on electrochemical behavior of 4-allyl-5-pyridin-4-yl-4H-1,2,4-triazole-3-thiol, the cyclic voltammograms of this compound were recorded in Britton Robinson buffer solution with various $\mathrm{pH}$. Figure 3 shows the cyclic voltammograms of 4-allyl-5-pyridin-4-yl-4H-1,2,4- 
triazole-3-thiol at $\mathrm{pH} \mathrm{2,} 8$ and 10 BRT buffer solution. As can be seen from this figure, the oxidation peak potential related with thiol oxidation was decreased by increasing $\mathrm{pH}$ value of buffer solution. This reflects that a proton transfer in the electrode process was participated.

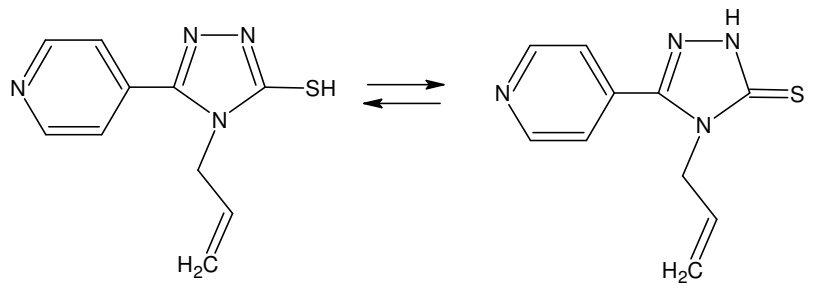

Figure 2. Thiole-thione tautomerism of 4-allyl-5-pyridin-4-yl-4H-1,2,4-triazole-3-thiol

In the cyclic voltammograms of 4-allyl-5-pyridin-4-yl-4H-1,2,4-triazole-3-thiol in all pHs, two oxidation peaks were observed. These peaks can be attributed to the oxidation of thiol groups. Electrochemical oxidation of this compound can be explained with electrochemical mechanism, because the electrooxidation leads initially to the generation of radical species with simultaneous $\mathrm{H}^{+}$release followed by a dimerization step. In the electrooxidation process of 4-allyl-5-pyridin-4-yl-4H-1,2,4-triazole-3-thiol, firstly thiol groups (R-SH) are changed to radical species (R-S) and give one $\mathrm{H}^{+}$and $\mathrm{e}^{-}$. Then disulphide (RS-SR) was formed by the chemical reaction of two mole radical species (Figure 4). The disappearance of the first anodic peak in the second scan of the cyclic voltommograms supported our discussion. As a result, it can be concluded that this thiol compound was oxidized irreversibly at GCE. Its oxidation process includes one oxidation electron transfer followed by a diemrization chemical step which shows that the oxidation behavior of this compound follows the EC mechanism in RSH compounds.
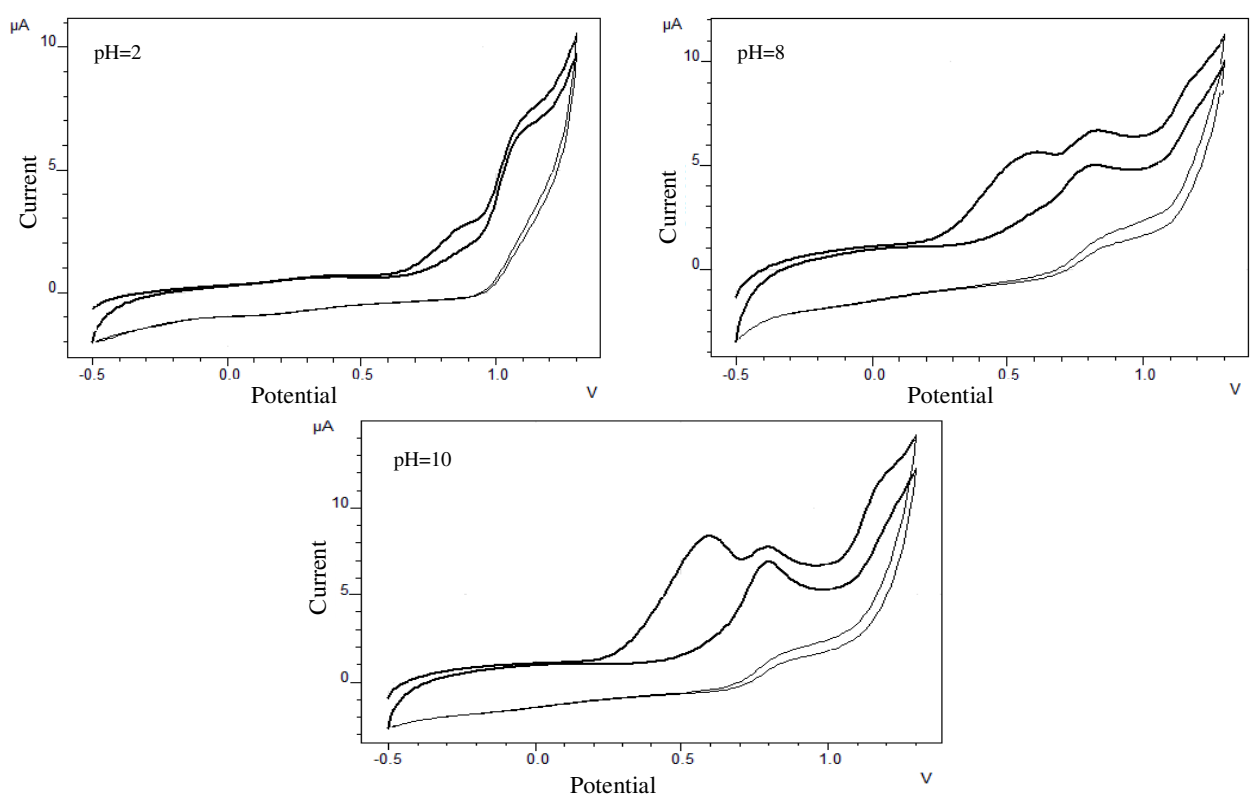

Figure 3. The $\mathrm{pH}$ dependence of the oxidation of 4-allyl-5-pyridin-4-yl-4H-1,2,4-triazole-3thiol 
When we evaluate the effect of $\mathrm{pH}$ on the oxidation peak current (Ip), Ip was increased and peak shape was apparent as sharply by increasing $\mathrm{pH}$ from 2 to 10 . When we take into consideration of electrochemical mechanism (EC), thiyl radical was formed in the first step (Figure 4). In this reaction, thiolic form is oxidized to radical form giving one $\mathrm{H}^{+}$and $\mathrm{e}^{-}$. Thus, radical species were strongly formed in the basic media due to easily releasing of $\mathrm{H}^{+}$. In addition, the solubilities of thione or thiol compounds in basic medium are higher than that acidic medium ${ }^{25}$. Due to the maximum peak current was obtained at the $\mathrm{pH} 10 \mathrm{BR}$ buffer solution, this supporting electrolyte was used for the recording of cyclic voltammograms of this compound at various scan rates. Thus, the electrochemical behavior of the triazole was investigated by recording cyclic voltammograms in BR buffer solution ( $\mathrm{pH}$ 10.0), at various scan rates. A typical cyclic voltammogram of triazole in the $\mathrm{pH} 10 \mathrm{BR}$ buffer solution at various scan rates was shown in Figure 5. The linear increase in the oxidation peak current with the square root of scan rate showed that diffusion controlled process was took placed in the oxidation of triazole compound ${ }^{25}$.

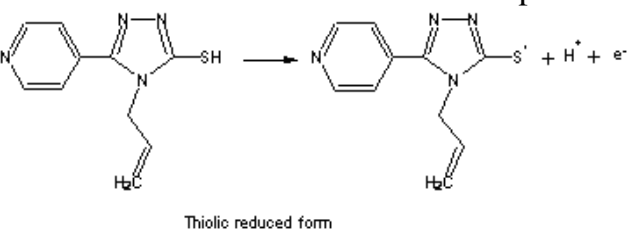

(B)

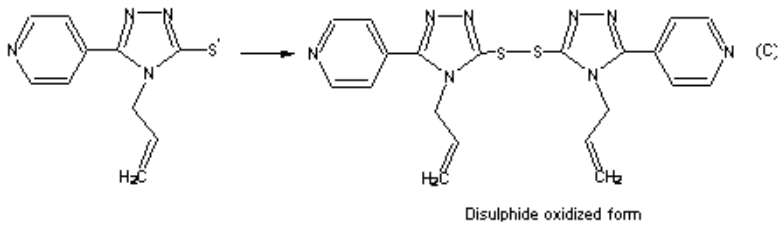

Figure 4. E: Electrochemical Reaction, C: Chemical Reaction
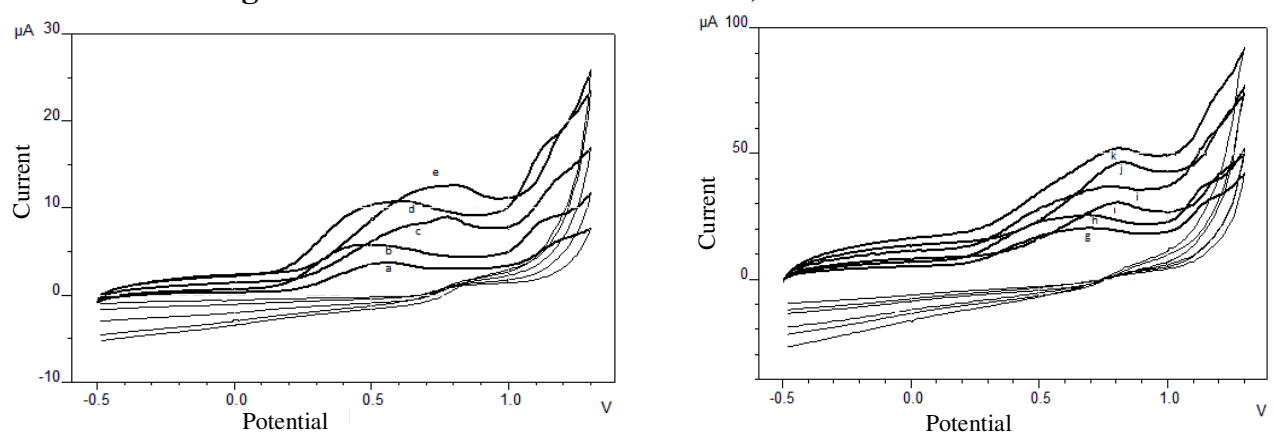

Figure 5. Cyclic voltammograms of 4-allyl-5-pyridin-4-yl-4H-1,2,4-triazole-3-thiol at GCE scan rates: a: $0.01 \mathrm{~V} / \mathrm{s}$, b: $0.02 \mathrm{~V} / \mathrm{s}, \mathrm{c}: 0.05 \mathrm{~V} / \mathrm{s}, \mathrm{d}: 0.08 \mathrm{~V} / \mathrm{s}$, e: $0.1 \mathrm{~V} / \mathrm{s}, \mathrm{f}: 0.2 \mathrm{~V} / \mathrm{s}, \mathrm{g}: 0.3 \mathrm{~V} / \mathrm{s}$, h: $0.4 \mathrm{~V} / \mathrm{s}, 1: 0.6 \mathrm{~V} / \mathrm{s}, \mathrm{i}: 0.8 \mathrm{~V} / \mathrm{s}, \mathrm{j}: 1.0 \mathrm{~V} / \mathrm{s}$

\section{Electrochemical impedance spectroscopy (EIS) measurements}

The corrosion behavior of mild steel in $0.1 \mathrm{~mol} / \mathrm{L} \mathrm{H}_{2} \mathrm{SO}_{4}$ solution, in the presence of these 4-allyl-5-pyridin-4-yl-4H-1,2,4-triazole-3-thiol inhibitions, was investigated by the EIS method at $25{ }^{\circ} \mathrm{C}$. Typical Nyquist diagrams in $0.1 \mathrm{~mol} / \mathrm{L} \mathrm{H}_{2} \mathrm{SO}_{4}$ containing compound 4-allyl-5-pyridin-4-yl-4H-1,2,4-triazole-3-thiol at different concentrations are shown in Figure 6. 

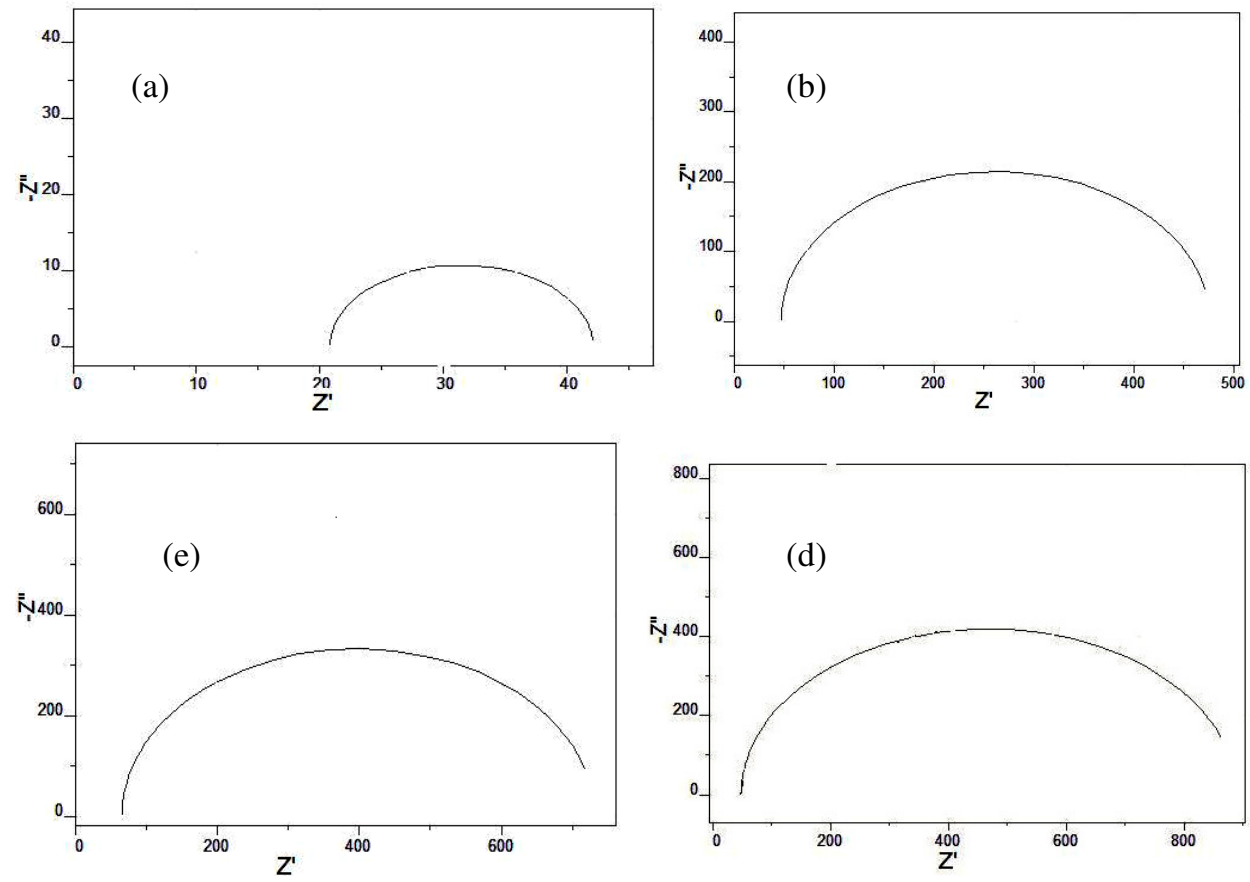

Figure 6. Nyquist plots for mild steel in $0.1 \mathrm{M} \mathrm{H}_{2} \mathrm{SO}_{4}$ at room temperature containing various concentrations of 4-allyl-5-pyridin-4-yl-4H-1,2,4-triazole-3-thiol: (a) 0.0 , (b) $10^{-5} \mathrm{M}$, (c) $10^{-4} \mathrm{M}$, (d) $10^{-3} \mathrm{M}$

As can be seen from the impedance results shown in Figure 6, it is obvious from the results that the 4-allyl-5-pyridin-4-yl-4H-1,2,4-triazole-3-thiol inhibits the corrosion of mild steel in $0.1 \mathrm{M} \mathrm{H}_{2} \mathrm{SO}_{4}$ solution at all concentrations used in this study was seen to increase with increasing additive concentration at $25^{\circ} \mathrm{C}$.

So as to confirm the corrosion inhibition ability of the 4-allyl-5-pyridin-4-yl-4H-1,2,4triazole-3-thiol derivative, scanning electron microscopy was applied. Figure 7 a shows the micrograph only surface polishing, Figure $7 \mathrm{~b}$ the morphology after exposure to the acid media for $3 \mathrm{~h}$, Figure $7 \mathrm{c}$ the morphology after immersion in $0.1 \mathrm{M} \mathrm{H}_{2} \mathrm{SO}_{4}$ solution of $1.0 \times 10^{-3} \mathrm{M}$ 4-allyl-5-pyridin-4-yl-4H-1,2,4-triazole-3-thiol for $3 \mathrm{~h}$.
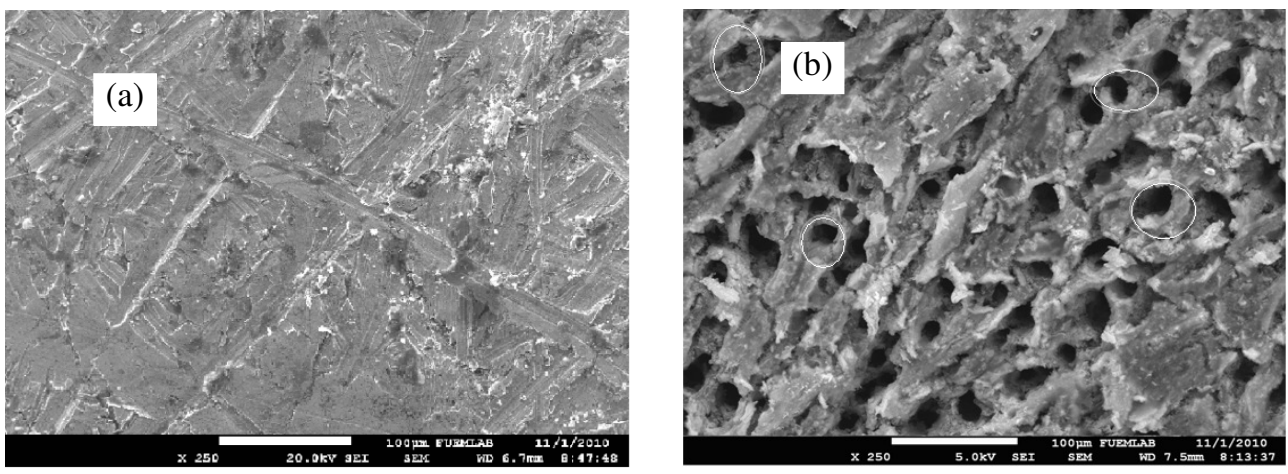


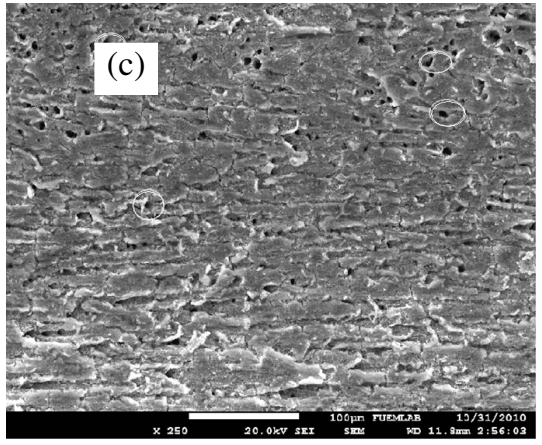

Figure 7. SEM micrographs of mild steel samples: (a) only surface polishing, (b) after immersion in $0.1 \mathrm{M} \mathrm{H}_{2} \mathrm{SO}_{4}$ solution without inhibitor (c) after immersion in $0.1 \mathrm{M} \mathrm{H}_{2} \mathrm{SO}_{4}$ solution of $1.0 \times 10^{-3} \mathrm{M}$ 4-allyl-5-pyridin-4-yl-4H-1,2,4-triazole-3-thiol.

\section{Conclusion}

Electrochemistry experiments were used to study the inhibitory effects of 4-allyl-5-pyridin4-yl-4H-1,2,4-triazole-3-thiol on mild steel corrosion in a $0.1 \mathrm{M} \mathrm{H}_{2} \mathrm{SO}_{4}$ solution at room temperature. The 4-allyl-5-pyridin-4-yl-4H-1,2,4-triazole-3-thiol derivative can be regarded as a good inhibitor for mild steel corrosion in $\mathrm{H}_{2} \mathrm{SO}_{4}$ solution.

\section{Acknowledgment}

The authors are indebted to the Firat University Research Foundation (FUBAP) for financial support of this work (Project no. 2059).

\section{References}

1. Quraishi M A and Shukla S K, Mater Chem Phys., 2009, 113, 685-689.

2. Bentiss F, Traisnel M, Gengembre L and Lagrenée M, Appl Surf Sci., 1999, 152, 237-249.

3. Bentiss F, Lagrenée M, Traisnel M and Gornez J, Corros Sci., 1999, 41(4), 789-803.

4. Bentiss F, Traisnel M, Chaibi N, Mernari B, Vezin H and Lagrenée M, Corros Sci., 2002, 44(10), 2271-2285.

5. Ramesh S and Rajeswari S, Electrochim Acta, 2004, 49, 811-820.

6. Touhami T, Aounti A, Abed Y, Hammouti B, Kertit S, Ramdani A and Elkacemi K, Corros Sci., 2000, 42(6), 929-940.

7. Algaber A S, El-Nemna E M and Saleh M M, Mater Chem Phys., 2004, 86, 26-32.

8. Branzoi V, Branzoi F and Baibarac M, Mater Chem Phys., 2000, 65, 288-297.

9. Quraishi M A, Sardar R and Jamel D, Mater Chem Phys., 2001, 71(3), 309-313.

10. Oguzie E E, Unaegbu C, Ogukwe C N, Okolue B N and Onuchukwu A I, Mater Chem Phys., 2004, 84, 363-368.

11. Oguzie E E, Onuoha G N and Onuchukwu A I, Mater Chem Phys., 2005, 89, 305-311.

12. Larabi L, Harek Y, Traisnel M and Mansri A, J Appl Electrochem., 2004, 34, 833-839.

13. Ebenso E E, Ekpe U J, Ita B I, Offiong O E and Ibok U J, Mater Chem Phys., 1999, 60, 79-90.

14. Benali O, Larabi L, Mekelleche S M and Harek Y, J Mater Sci., 2006, 41, 7064-7073.

15. Zhang S, Tao Z, Li W and Hou B, Appl Surf Sci., 2009, 255, 6757-6763.

16. Ramesh S, Maruthamuthu S, Rajeswari S, Mater Lett., 2003, 57, 4547-4554. 
17. Stupnisek-Lisac E, Soric T and Podbrscek S, J Appl Electrochem., 1994, 24, 779-784.

18. Quraishi M A and Sardar R, Mater Chem Phys., 2003, 78, 425-441.

19. Tao Z, Zhang S, Li W and Hou B, Corros Sci., 2009, 51, 2588-2595.

20. Li W, Zhao X, Liu F and Hou B, Corros Sci., 2008, 50, 3261-3266.

21. Berchmans L J, Sivan V and Venkata Krıshna Iyer S, Mater Chem Phys., 2006, 98, 395-400.

22. Trachli B, Keddam M, Takenouti H and Srhiri A, Corros Sci., 2002, 44, 997-1011.

23. Tang L, Mu G and Guangheng L, Corros Sci., 2003, 45, 2251-2262.

24. Koparır M, Çetin A and Cansız A, Molecules, 2005, 10(2), 475-480.

25. Dilgin Y, Cansız A, Çetin A, Kutulay P, Oral A and Yılmaz S, Asian J Chem., 2007, 19, 3221-3227. 